\title{
Fostering rigour in accounting for social sustainability
}

\section{Paper by:}

\section{Brendan O'Dwyer}

University of Amsterdam Business School and Royal Holloway, University of London

\section{Jeffrey Unerman}

\author{
Royal Holloway, University of London
}

\begin{abstract}
This paper illuminates how a journal and its editor can initiate and foster a stream of high quality and influential research in a novel area. It does this by analysing Accounting, Organizations and Society's (AOS's) and Anthony Hopwood's nurturing of research into key aspects of accounting for social sustainability for several decades before this research area became established. Our discussion unveils how the initiation of unique research areas may initially involve the publication of risky papers driven primarily by passion. Through the steering of a journal editor, subsequent work can proceed to combine this passion with academic rigour and produce research insights that can benefit society by positively influencing policy and practice. It is this attention to rigour that we argue needs to be central to future research in accounting for social sustainability (and accounting for sustainability more broadly) if it is to continue producing purposeful knowledge. We offer several substantive directions for future research aimed at producing such knowledge.
\end{abstract}

\section{Acknowledgements:}

We are very grateful to Jan Bebbington, Christopher Chapman, David Cooper, Kari Lukka, and to participants at the Accounting, Organizations and Society $40^{\text {th }}$ Anniversary Workshop at London School of Economics and Political Science in May 2015 and at the CSEAR France conference in June 2015 for their invaluable comments on earlier drafts of this paper. 


\section{Introduction}

This paper aims to illuminate how a journal and its editor can be influential in fostering a stream of high quality and influential research in a novel area. It does this by analysing Accounting, Organizations and Society's (AOS's) fostering of research into aspects of accounting for sustainability across several decades. An important element in $A O S$ 's encouragement of research in this area was the risks its founding editor, Anthony Hopwood, was willing to take in supporting innovative accounting for sustainability research - as part of his ambition to re-define the intellectual landscape of accounting (see: Chapman, Cooper, \& Miller, 2009).

Given the breadth of issues underlying accounting for sustainability, to provide a sufficiently narrow analytical focus for this paper we examine the role of $A O S$ in nurturing a research stream seeking to enhance social sustainability through examination of the democratic functioning of information flows to stakeholders other than providers of financial capital. Cooper and Morgan (2013) explain that literature in this field recognises that accounting (including corporate reporting) influences the culture of society, especially what is seen as important in society and for what organizations are understood to be responsible and accountable. This domain affords primacy to a notion of the public interest that extends beyond the needs of capital providers in discussions of accounting and reporting, through examining and seeking to design reporting that addresses issues of stewardship in corporate accountability (Harte \& Owen, 1987; Owen, 1990). Although AOS and Hopwood also supported the development of research in other areas of accounting for sustainability (such as environmental accounting), it is through this particular aspect of social sustainability that this paper highlights the manner in which a journal and its editor can nurture, influence and help shape a novel field of research.

We recognize that journals other than $A O S$ also have long track records of proactive and effective support for research into these issues (for example: Accounting, Auditing and Accountability Journal, Critical Perspectives on Accounting, Social and Environmental Accountability Journal and Accounting Forum). However, as this paper does not aim to provide a comprehensive literature review of the area of social sustainability upon which we focus, but rather to examine the manner in which a journal and its editor can influence the development of a research area, we consider a focus on key papers published in $A O S$ to be appropriate. We do, however, recognize that a limitation of this paper is that we do not have 
space to discuss influential papers published in other journals (see, for example: Bebbington \& Gray, 2001; Gray, Dey, Owen, Evans, \& Zadek, 1997; Neu, Cooper, \& Everett, 2001; Tinker, Lehman, \& Neimark, 1991) which we would have addressed had this paper taken the form of a more broadly-based comprehensive literature review of the field of accounting for social sustainability.

As in other areas of accounting (and broader social science) research, insights from accounting for sustainability research have had the potential to provide a robust evidence base upon which more effective policies and practices can be developed (Unerman \& Chapman, 2014). This influence has been realised where such research has been underpinned by a commitment to rigour. While much of the recent expansion of accounting for sustainability research exhibits this commitment, we argue that this needs to become more widespread. As Gray (2002) noted when reviewing the smaller earlier body of social and environmental accounting research from the late $20^{\text {th }}$ century, accounting for sustainability research needs to be continually wary of combining too much apparent passion with too little rigour.

While progress requires that there must always be scope for individual researchers to motivate a community of researchers to focus on novel research problems, researchers who are passionately interested in a novel issue also need to demonstrate that the issue is nontrivial and of broader interest and relevance before developing a research programme to address it. So, while passion can be very effective at motivating an array of research questions, a filter needs to be applied in deciding which of these questions are reasonably justifiable to pursue. As an example of research issues which we have recently seen in accounting for social sustainability that we do not regard as having successfully passed through this filter: where individual organizations do not have a material responsibility for a particular sustainability issue, there is little merit in undertaking research into organizational management or discharge of accountabilities for this issue (Unerman \& Zappettini, 2014). Conversely, in the conclusions to this paper we highlight some novel substantive issues which could form the basis of future research programmes.

Once appropriate research questions have been established, they need to be addressed in a dispassionately rigorous manner. They cannot simply be driven by a priori judgements on what the answers should be - where evidence could be drawn upon selectively to give a desired answer. As Neu, Cooper and Everett (2001, p. 740) warn us: "with only a concern for 
the ends, any means [can] be justified". Where research is not "based on sound argument, reasoning and demonstration" (Neu et al., 2001, p. 740), at best it will be ignored and will thereby miss an opportunity to influence developments in policy and practice. At worst, it will be taken up by policy makers and practitioners and have an adverse influence on the resulting policies and practices, and risk damaging the reputation of the academic community.

Motivating research questions within the specific area of social sustainability that this paper focuses on, the literature identifies four core principles: human well-being, equality, democratic government, and democratic society (Magis \& Shinn, 2009). In practice at the organizational level, these four principles are manifest in issues such as fairness in distribution and opportunity, adequate provision of social services, including health and education, gender equity, and political accountability and participation (Dillard, Dujon, \& King, 2009). Among the major issues arising for organizations with respect to these aspects of social sustainability, therefore, are their interactions with employees, suppliers, communities and consumers. These include employment terms and conditions, union recognition and interactions, supply chain impacts such as human rights abuses in supply chains, impacts on communities comprising health impacts, displacement of communities, socioeconomic impacts when organizations leave communities, and consumer impacts such as product safety and responsible advertising (Bebbington \& Dillard, 2009, p. 158). The early work in $A O S$ we revisit in this paper pays particular attention to a small selection of these themes, especially as they relate to (reporting to) employees and communities. Research questions in this early work were constructed from perceived 'real world problems' (see: Alvesson \& Sandberg, 2011, 2013) surrounding the nature of corporate reporting.

We complement our analysis of insights from papers and debates published in $A O S$ that profoundly influenced our understanding with an explanation of some of Hopwood's interactions with policy and practice in accounting for (social) sustainability. We thereby reflect not only on the development and influence of themes surrounding specific aspects of accounting for social sustainability underlying key papers published in $A O S$, but also on Hopwood's influence on both academic work and public policy in this area. We subsequently draw on both these elements to provide an informed, albeit personal, view of fruitful future directions for research in this area.

Before examining some of the significant insights published in $A O S$, we explore the context within which the journal nurtured this strand of research. In so doing, we explain the 
influence of two early papers - one polemic on accounting and social sustainability published in the first volume of AOS (Medawar, 1976) and a later paper that, while not specifically focused on issues of social sustainability, we regard to be key in adding renewed academic rigour to research studies examining issues in this area (Cooper \& Sherer, 1984). We also explain Hopwood's fostering of research in this area - through insights from his key editorials that addressed 'accounting and sustainability' and through his policy work around accounting for sustainability.

\section{Setting the $A O S$ agenda and challenge on accounting for social sustainability}

Contributions to learned journals traditionally mark their work by the self-denying use of pronouns (to denote objectivity) and by the inclusion of suitably humble, and sometimes unctuous, acknowledgements to the effect that the presence, or even the bias, of the observer might possibly have influenced the course of the events being described. I shall depart from this tradition. I want to emphasise that my colleagues and I at Social Audit are biased - and that that bias underpins our interest in our work. (Medawar, 1976, p. 389)

The quotation above is taken from a short paper by Charles Medawar (1976) published in the first volume of $A O S$ which signified an explicit beginning for $A O S$ as a journal in which accounting for social sustainability was set up for examination (see also, Hopwood, 1978a). Medawar's paper proved inspirational for a set of papers elucidating themes of critical engagement, stakeholder accountability, and public policy impact.

We consider Medawar's paper to be an essential entry point to our review for a number of reasons. First, it is a polemic which is highly normative and does not make explicit use of theory, other than a broad conception of social accountability as "a process in which those within corporate bodies, with decision making powers, propose, explain and justify the use of those powers to those without" (Medawar, 1976, p. 393). Hence, it is an agenda-setting paper driven more by passion than academic rigour, and would likely not be published in a leading academic journal in today's academic environment (see: Hopwood, 2007; Humphrey $\&$ Gendron, 2015). Second, it focuses on assessing and enabling democratic ideals which are central to our interpretation of accounting for social sustainability. Third, Medawar perceives a limited role for accountants (and accounting academics) in fulfilling these ideals through forms of social accounting and social audit, a position he reiterated nine years later in private 
correspondence with Hopwood (Hopwood, 1985). He regarded accountants as being associated with quests for acceptable, objective and verifiable measurement techniques and questioned the commitment of accountancy and accountants to designing reporting mechanisms in the public interest. Fourth, Medawar prioritised those who he regarded as needing information rather than those who possessed it, and argued that the benefit of the doubt should be given to broad stakeholder groups such as employees and local communities. Through his polemic, Medawar, in effect, laid down a challenge in AOS to accountants and accounting academics whom he did not entirely trust to develop substantive and effective 'social accounting' (or accounting for society).

Medawar's paper was published in, and reflective of, a particular 1970s' UK social and political context in which the need for and means of reporting to employees and trade unions was being actively considered and the broad concept of 'social accounting' was entering accounting discourse (Burchell, Clubb, \& Hopwood, 1985). Tricker (1975) placed accounting firmly within this social and political context in his call for the major UK research funding body, the SSRC (Social Science Research Council), to support research examining the changing social context of accounting - given that accounting practice in the UK was becoming central to many prominent national policy debates (Hopwood, 1985).

Accounting influences at this time within the UK ranged from discussions surrounding inflation accounting to the publication of The Corporate Report which advocated stewardship as an important aspect of the 'public accountability' of organizations. The Corporate Report articulated a need to broaden the scope and nature of corporate reporting, through, inter alia, the publication of value-added statements showing how the benefits and efforts of an enterprise were shared between employees, capital providers, the state and reinvestment (Burchell et al., 1985, p. 386). Its controversial recommendations about expanding reporting scope were largely accepted by the UK government - despite the protestations of the accounting profession - and by the late 1970 s more than $20 \%$ of UK companies were producing value-added statements (Burchell et al., 1985).

The SSRC also set up a committee to advance the understanding of the social and political nature of accounting and the social relevance and usefulness of accounting practice (see, Hopwood, 1985). While the committee did not produce a final report, Hopwood's 1985 AOS paper reflecting on the committee's deliberations indicated that such a report would have contained a key recommendation that the SSRC should commission engagement- 
focused 'action research'. Much of this would examine the actual (and potential) use of accounting data within social and political contexts, particularly with respect to attempts to relate extensions in accounting practice to the furtherance of a range of social interests.

This resonates with the theme of Medawar's (1976) AOS polemic on social accounting. Given Medawar's normative orientation and lack of explicit theorization, his paper was a testament to the early publication risks $A O S$ was willing to take and to the attention that Hopwood devoted to alternative thinking about the role of and relationship between accounting and the social. Medawar's paper also indicated, albeit implicitly, certain key themes that scholars writing in $A O S$ would soon seriously address: a broad conception of accountability focused on the information needs of employees and local communities, the centrality of critical engagement, and the significance of seeking policy impact.

Cooper and Sherer (1984) echoed Medawar's call for "the creation of accountings that [we]re valuable in society" (p. 208) and for a greater understanding of accounting in the context of the social, political and economic environment in which it operated (p. 225; see also, Tinker, 1980). They critiqued the economic consequences analysis approach to understanding and valuing the role of accounting reports in a broader societal context, as they regarded this approach as being overly fixated on the consequences of the reports for the behaviour and interests of the shareholder and/or corporate manager, while largely ignoring users such as employees, trade unions and governments. Cooper and Sherer (1984) were also early proponents of direct engagement research, aimed at countering the limited evidence in the literature concerning the way managers actually arrived at their attitudes or decisions ( $\mathrm{p}$. 216), a concern that pervaded Hopwood's early writings in $A O S$ (see: Burchell, Clubb, Hopwood, \& Nahapiet, 1980; Hopwood, 1976, 1978b, 1983, 1985, 1987).

Their urging for researchers to be explicitly normative, descriptive and critical is to us one of the core clarion calls to those researching accounting for social sustainability. Key aspects of these themes pervaded some early pioneering AOS papers in accounting for social sustainability by Harte and Owen (1987) and Owen and Lloyd (1985), and were also evident in Cooper and Essex (1977) prior to Cooper and Sherer's 1984 paper.

We revisit these early papers below, which mobilised Medawar's call for a reporting focus on the information needs of groups other than shareholders, and prioritised engagement-based research partially focused on articulating public policy recommendations. Before moving on to consider the contributions of these papers, we briefly highlight key 
elements of Hopwood's long-standing commitment to developing policy in this area. This commitment helps provide additional context to understand the commitment of $A O S$ to developing and nurturing this strand of research.

\section{Policy commitment and editorial steering}

Hopwood's support for the development of accounting for social sustainability was evident both in his writings and editorial actions in the early days of $A O S$. It was also manifest in his engagement with policy bodies. For example, he was later a board member of the Prince of Wales's Accounting for Sustainability Project (A4S), which sought to develop mechanisms to help organizations embed connected understandings and appreciations of sustainability in their decision-making and reporting. A4S explicitly recognized three main elements to long-term sustainability: social, environmental and economic. A key feature of A4S was an attempt to use reporting to instigate some form of organizational and public policy change - a feature that resonated with the aims of Medawar (1976) and Cooper and Sherer (1984) (and Harte \& Owen (1987) and Owen \& Lloyd (1985) as discussed below). In arguing for the interconnectedness between and importance of these three elements, Hopwood's influence and insights into the importance of social sustainability were evident. This was the latest of his active encouragements for the development of public policy that helped develop the roles of accounting in enhancing social sustainability.

In light of Hopwood's concern to encourage studies of accounting in action, at the beginning of 2009 A4S commissioned a research project comprising in-depth case studies of the way eight large public and private sector organizations had engaged with the principles and practices underlying Accounting for Sustainability (including A4S's Connected Reporting Framework). In initiating this project, Hopwood yet again demonstrated his belief in, and commitment to, engagement with policy and practice as a way to help improve the sustainability of the social world and the environment.

Although the Accounting for Sustainability case studies had been motivated by a desire to use academic expertise to provide a robust, while accessible, evidence base to further policy and practice, Hopwood was also concerned to use the insights to advance the academic literature. He therefore decided to use a later special section in $A O S$ to publish explicitly and robustly theorized insights from the case study work. The special section was published in $A O S$ in 2014, some years after Hopwood's' untimely death, but as a fitting tribute to his influence in advancing research in this area - and to his long-standing 
commitment to and steering of this strand of research in $A O S$. We now turn to an exploration of the $A O S$ papers we consider to have been core to this unfolding strand of research.

\section{Assessing stewardship and facilitating employee decision making}

A focus on the information needs of user groups other than shareholders, especially employees and trade unions, pervaded Cooper and Essex (1977). They argued that 'accounting should not develop in isolation from society' (p. 202) and were positively assertive, in contrast to Medawar (1976), about the role accountants could and should play in identifying union and employee decision models which could contribute to employee welfare $^{1}$. They argued, however, that employees' and unions' own perceived needs for information should not be prioritised, but that a decision-orientated approach focusing on the decisions that these users should be taking needed to be developed. Only then, they claimed, could the information that was actually needed be considered, as this could then be matched with the decision models that, for example, employee representatives should be using. Hence, user needs as opposed to wants were to be prioritised.

An implicit plea for enhanced engagement was evident in their call for research to observe the decision-making of employee representatives. This was consistent with their concern to encourage the reporting of relevant information as, without relevance, the information reported might only allow marginal adjustments to the status quo. Moreover, they suggested that accountants should become involved in producing reports relevant for decisions about an enterprise rather than just reports on an enterprise.

Harte and Owen (1987) developed the theme of engagement and the focus on employee users of corporate reports in their efforts to establish a normative framework for social cost analysis in the context of de-industrialisation in the UK. They focused on local governments in the UK as important users of corporate information while lamenting the lack of accountability to workforces and local communities when large-scale manufacturing industries were closed down. They contended that it was an indictment of corporate reporting

\footnotetext{
${ }^{1}$ Rob Gray, Jan Bebbington and colleagues effectively countered many of Medawar's concerns in their extensive work exploring a social role for accounting (see, for example: Gray et al., 1997; Bebbington \& Gray, 2001; Bebbington and Larrinaga, 2014; Bebbington, Brown, Frame, \& Thomson, 2007). David Cooper and colleagues such as Dean Neu, through their activism and academic work have also issued effective (implicit) ripostes to Medawar's concerns about the trust that should be placed in accounting academics. They have sought to integrate the theoretical and praxis components of accounting scholarship by intervening in the public domain (see, for example: Everett, Neu, Rahaman, \& Maharaj, 2015; Neu et al., 2001).
} 
that accounting reports offered no indication of the public costs of the unemployment created by plant closure decisions - a major social sustainability issue. They elaborated on the absence of 'true accountability' - also alluded to by Medawar (1976) - because, while information provision could assist in forming judgements, labour representatives also needed the power to hold private enterprise to account. As existing legislation prevented this possibility, they posited that local government could be better able to exercise this power. Harte and Owen (1987) were openly normative in arguing for the existence of a social contract between local governments and business to support their case for business to be held accountable to local communities when divestment decisions were made. Their 'true accountability' notion represented an explicit acknowledgment of a broader stewardship role for accounting and accountants.

In formulating their recommendations, Harte and Owen (1987) critically evaluated existing social cost analyses conducted by local authorities in the wake of plant closures. While their analysis was robust in the context of studies of the time, it did not explicitly assemble theory to help understand why the practices were enacted in the manner they were. However, their desire to pursue policy impact was palpable in their critique and in their proposed framework charting what they contended local authorities should require from reporting on the social costs of closures. They concurred with Cooper and Essex (1977) that reporting should assist decisions about an enterprise rather than merely reporting on an enterprise. Both papers acknowledged a broad decision-usefulness role for reporting information while simultaneously signalling a stewardship role.

These papers also encouraged enhanced researcher engagement. Harte and Owen (1987) encouraged research examining what local government saw as its role in relation to business during a period of de-industrialisation in order to assist in developing a detailed framework that they felt could then be tried and tested. They refer to conversations they had with local government planning departments and, from these, derived four roles for social accounting and reporting: a reactive role; a positive use role; a regular monitoring role; and an educational use role. Cooper and Essex (1977) argued that research should observe the decision-making of employee representatives; a call consistent with their concern to encourage a focus on the reporting of relevant information.

In a related study, Owen and Lloyd (1985) examined the role of financial information in company- and plant-level bargaining between managers and employees. They critiqued a 
tendency among a suite of SSRC-funded studies to assume a universal 'identikit' employee representative in their consideration of the use of (financial) information in companyemployee bargaining processes. With respect to the SSRC studies, they concluded that this was surprising given that these studies comprised nuanced cases of a form of 'accounting in action' in which the use of information in company- and plant-level bargaining was studied. Hence, while applauding the rich contextual detail of the SSRC studies (p.331), they criticised the rather general nature of many of the studies' conclusions. Moreover, they sought to address a key issue which they felt these studies ignored: the reasons for the low rates of utilisation of corporate financial information by union negotiators.

Owen and Lloyd (1985) were critical of the normative approach adopted by Cooper and Essex (1977) that sought to specify a universal decision model for union representatives. For them, this represented a potentially fruitless search for universal objectives given that many union/employee users differed in their objectives. Cooper and Essex (1977) were accused of failing to develop their arguments sufficiently with respect to identifying exactly the differing nature of employee representatives and the diverse organizational contexts in which negotiations took place.

Owen and Lloyd (1985) offered a tentative analytical framework designed to assist future researchers more rigorously consider the contexts within which various trade union representatives used financial information. This, they argued, would unlock research into differing approaches to financial information use by assorted union representatives, a call McBarnet, Weston, and Whelan (1993) responded to in AOS some years later. Owen and Lloyd's (1985) explicit purpose was not only to contribute academically but to also offer insights for policy development; a concern consistent with the fact that by the time the paper was published, one of its authors, Anthony Lloyd, was a UK Member of Parliament.

What these initial studies share is a commitment to expanding the horizons of accounting to incorporate a specific aspect of accounting for social sustainability - the nature and focus on reporting by companies to employees or their representatives. While not always explicitly stressed, engagement is emphasised and the importance of holding managers to account predominates ${ }^{2}$. There is, however, also a decision-usefulness emphasis embedded in

\footnotetext{
2 The disclosure of financial/accounting information to employees and trade unions was an issue that engendered much debate in the pages of AOS around this time. For example, while Ogden and Bougen (1985) outlined some negotiation benefits for trade unions in using accounting information disclosed by management, they also warned that unions needed to tread carefully as they would "become exposed to the latent ideological
} 
this work, albeit one focused on a broad set of corporate stakeholders. These studies were very much of their time: a UK economic and political context infused with industrial conflict. As Hopwood $(2005$, 2007) later observed, these papers were largely driven by passion characterised by commitment, raw curiosity and a desire to ruffle the conservative mainstream of accounting research through prioritising the social functioning of accounting. They sought to significantly enhance our knowledge and stimulate debate. The act of publishing was merely one part of a process ultimately aimed at a more holistically-oriented and rigorous development of evidence and insights. The core impetus underpinning this work was simultaneously sustained by a stream of $A O S$ papers authored by Hopwood and others exhorting a focus on 'accounting in action' fuelled by methodological and theoretical innovation (see, for example: Burchell et al., 1980; Hopwood, 1983, 1987; Miller \& O’Leary, 1987).

In the 15 years after the papers discussed above, there was a notable absence of major work published in $A O S$ that advanced the specific themes developed in these papers (see, however, Lehman, 1999). The next key paper in $A O S$ that we regard as directly addressing these issues is a review paper by Gray published in 2002 in which he, inter alia, addressed the possible reasons for this absence.

\section{Whither accountability, engagement and theory? Reflecting on absence in $A O S$}

While, during the 1990s, some important work was published in AOS examining aspects of accounting for environmental sustainability (see: Gray, 1992; Neu, Warsame, \& Pedwell, 1998; Rubenstein, 1992) substantive work focusing on accounting specifically for social sustainability was largely absent from the pages of the journal for a considerable period. This absence was at a time when social and organizational concerns for sustainability were focused primarily on shorter-term economic sustainability, but also with a small and growing emphasis on environmental sustainability (with little explicit recognition of the social goals underlying such economic and environmental sustainability). This was evident in accounting and reporting practices that reported on economic and environmental sustainability (Gray, 2002).

conditioning such information entail[ed]" (p. 222) and would enter a discourse that was exclusively managerial in its rationale. Craft (1981) actually argued, albeit in a nuanced manner, that disclosure to employees was often unwarranted and inappropriate. 
Gray (2002) reflected on this absence in his review of what he broadly termed 'social accounting' research. He regretted that very few of the themes of the early papers were taken forward by papers in $A O S$. Gray also noted a continuance of what he termed 'US-style empiricism' in social and environmental reporting papers published in $A O S$ from the mid1980s to the early to mid-1990s, which largely ignored wider user groups. He argued that the 'social accounting' literature was failing as an academic endeavour due to its underdeveloped theorization and preference for passion over rigour, characteristics which he regarded as inevitably contributing to its absence from the pages of $A O S$. However, an alternative perspective on this absence could be that with few organizations engaging in (specifically) social, rather than environmental, reporting, or other accounting practices in this area, there was too little contemporary empirical material or policy interest to provide a substantive evidence base for rigorous research work of this nature. Gray (2002) argued that possibly inappropriate criteria in some journals might also hinder academic endeavour in areas where there is little current practice to build upon.

Gray (2002) outlined a future focus for researchers aimed at learning how to write and theorize engagement. However, his key concern, an issue we will return to later, was the absence of a greater meta-theory for 'social accounting' (p.703). He considered this necessary in order to discover what it was that social accounting scholars were really interested in and why. He also appealed for social accounting to cease chasing the latest fad - at this time, issues surrounding accounting and the physical environment were prominent - and he asked: "whatever happened to employees? Are they unimportant these days? I should have thought not" (p.703). In making these calls, Gray reiterated the hopes and aspirations expressed in the earlier papers by Owen and Harte (1985), Owen and Lloyd (1987) and Cooper and Essex (1977).

\section{A tentative evolution in theorized engagement}

After Gray (2002), between 2002 and 2009 a number of field studies into accounting for social sustainability were published by $A O S$. In adjacent journals such as such as Accounting, Auditing and Accountability Journal (AAAJ) and Critical Perspectives on Accounting (CPA), theorized engagement in this area also became more prominent (see, for example: Bebbington et al., 2007; Neu et al., 2001) and Gray's (2002) exhortations were often enrolled in support of certain foci. The social sustainability work appearing in $A O S$ in 
this period was, however, sometimes not explicitly theorized (O'Dwyer, 2005) or was underpinned by broad theorization mobilising overly general conceptions of legitimacy (see, for example, Deegan \& Blomquist, 2006). These studies focused on the problems, both organizational and institutional, of accounting for social sustainability and emphasised the apparent impossibility of achieving Medawar's ambition of 'true accountability' (Cooper \& Owen, 2007; O'Dwyer, 2005). Little of the positive, solution-oriented focus of Cooper and Essex (1977) and Owen and Harte (1987) was evident.

During this period, Unerman and Bennett (2004) departed from this trend. They mobilised Habermasian discourse ethics to offer a theoretical model for determining corporate social, environmental, economic and ethical responsibilities, thereby placing a simultaneous focus on organizational-stakeholder engagement. Unerman and Bennett (2004) revisited the earlier theme of democratic corporate accountability and assessed how features of the moral consensus-building discourse criteria of an ideal speech situation advocated by Habermas could be incorporated into stakeholder engagement using the internet. Their assessment of the potential of Shell's stakeholder dialogue 'web forum' to conform to this ideal speech situation sought to produce practical policy insights, which have subsequently become more pertinent with the evolution of social media. The paper combined the engagement and public policy focus of the earlier work by Harte and Owen (1987) and Owen and Lloyd (1985). However, unlike this prior work, Unerman and Bennett (2004) made explicit use of theory in a way that enhanced the robustness of the insights and understanding they provided.

O'Dwyer (2005) developed the theme of stakeholder accountability in his in-depth field study of a social accounting process in an overseas aid agency. He highlighted the intense complexity and petty politics involved in realising democratic ideals within these processes. Consistent with Unerman and Bennett (2004), he unveiled the nature of the difficulties less powerful stakeholders, including employees, have in holding management to account, especially when information is undisclosed or inherently flawed. However, while offering a rich case analysis, theorization in O'Dwyer (2005) was largely implicit and represented something of a missed opportunity to further develop many of the emerging theoretical ideas introduced by Unerman and Bennett (2004).

Following on from Unerman and Bennett (2004), Cooper and Owen (2007) drew, albeit tentatively, on Habermas's ideal speech situation to evaluate the extent to which 
increased sustainability reporting in the UK had operated to enhance "extra-corporeal" accountability (Roberts, 2003) through empowering those most vulnerable to the effects of corporate conduct. They cited Cooper and Sherer (1984) in support of their avowedly normative stance and articulated an ambition to advance public policy debate (p. 653). They reintroduced employees as a key reporting stakeholder and, consistent with Cooper and Essex (1977) and Owen and Lloyd (1985), focused on the effective utilization of information by empowered employee recipients.

In a 2009 AOS editorial on accounting for sustainability, Hopwood (2009) reflected upon the role of A4S. He noted its Connected Reporting Framework's efforts to move beyond a static aim of merely reporting and to introduce a dynamic element into organizational life. The Connected Reporting Framework sought to stretch existing corporate policies and actions rather than radically change them, a focus with which Medawar (1976) may not have been entirely comfortable. Hopwood applauded this attempt to integrate an explicit consideration of organizational change processes into the design of a reporting system. While Cooper and Essex (1977) and Harte and Owen (1987) sought to develop decision-making frameworks aimed at assisting users such as employees, Hopwood (2009) aimed at fostering the introduction of new forms of information into organizational decisionmaking and external reporting and therefore focused more explicitly on shaping organizational behaviour in order to facilitate particular user groups.

Our reading of Hopwood's 2009 editorial reinforces the view that he had long been giving serious thought to issues surrounding accounting for social sustainability. Similar to Gray (2002), with whom he had corresponded while writing the editorial, he expressed concern at the continuing absence of (theorized) field studies (although these were, by now, being published in other journals such as $A A A J$ and $C P A$ ). He returned to the theme of broader-based reporting prevalent in Cooper and Sherer (1984) and Harte and Owen (1987), suggesting that this remained an area in urgent need of more research - especially as reporting could actually reduce what was known about a company and its activities, thereby acting as a form of corporate veil (p. 437). Consistent with Medawar (1976), Cooper and Essex (1977) and Harte and Owen (1987) he sought relevant information and preferred to focus on those who needed information rather than those who possessed it. 


\section{Theorized engagement and public policy impotence}

Subsequent to Hopwood (2009), Archel, Husillos, and Spence (2011) took up the mantle of Owen and Lloyd (1985), Harte and Owen (1987) and Cooper and Essex (1977). They did this through their case study of a government-initiated stakeholder consultation process in Spain designed to propose measures aimed at stimulating responsible and sustainable business behaviour and reporting. Participants included NGOs, publicly listed companies, academics and trade unions. While the consultation process did not have the exclusive employee focus of Harte and Owen (1987) and the other earlier studies, it contained many of their core ingredients. For example, one of the consultations comprised a tripartite forum of government representatives, Spain's most influential employer's association, and the two largest Spanish trade unions. Archel et al. (2011), while not citing any of the earlier relevant $A O S$ papers discussed above, adopted many of their tenets. They also reflected the changing institutional context within which issues surrounding accounting for social sustainability were now being discussed.

While the early papers by Harte and Owen (1987) and Owen and Lloyd (1985) sought to improve engagement processes and the reporting and decision-making therein, Archel et al.'s (2011) theoretically informed analysis led to the conclusion that efforts of this nature were futile in the Spanish context. Their analysis illustrated how stakeholder consultations legitimated dominant, business-as-usual discourses on corporate social responsibility (see also, Malsch, 2013). Harte and Owen (1987) and Owen and Lloyd (1985) had attributed significant agency to trade unions in effectively invoking change through engagement that drew on the disclosure of relevant information, admittedly at a time when, and in a context where, they were much more powerful. In contrast, Archel et al. (2011) accused the trade unions they studied of acting in concert with the corporate sector and effectively silencing voices from civil society, thereby leaving civil society without any countervailing power to unite around. They also argued that the unions played a role in institutionalising a CSR discourse contradicting the interests of civil society and, in the long term, the interests of their own membership. Given the non-mandatory nature of the proposals emerging from the consultation process studied, Archel et al. (2011) deemed it unlikely that other civil society groups would be able to hold corporations to account even if stakeholder consultation processes were improved. They advanced the accounting for social sustainability literature through their rigorous use and development of theory, their focus on contemporary engagement practices, and, in particular, their insights on the institutional context examined. 
While they made a significant contribution to advancing the literature, their conclusions shared with Gray (2010) a view that accounting for social (and environmental) sustainability was a futile practice. This mobilised their apparently firm a priori normative view that any engagement with the corporate sector would inevitably be captured and would consequently fail to further social sustainability.

\section{Theorized engagement: contesting calls for greater meta-theory}

After the above papers, the next work published in $A O S$ specifically focused on accounting for social sustainability was in the 2014 special section on Accounting for Sustainability (see also: Nicholls, 2009, 2010). In their agenda-setting introduction to the special section, Unerman and Chapman (2014) argue that some academics seem to believe there to be a risk that the kind of intellectual investment necessary to understand theory is perceived as a distraction from important and practically relevant work; a concern implicit in Gray's (2002) earlier review. However, as the Accounting for Sustainability research project revealed, this is a fallacy and theorized engagement of the social should take centre place in the accounting for social sustainability literature if the academy is to provide answers to socially significant research questions.

In the 2014 special section, rigour through theoretically informed analysis of engagement, stewardship and transparency was prevalent. Spence and Rinaldi (2014) examined accounting-based decision-making mechanisms designed to enhance sustainability management and social responsibility among organizations in a supply chain, a central social sustainability issue. Thomson, Grubnic, and Georgakopoulos (2014) sought to understand how government policies aimed at enhancing sustainability and improving social justice in the delivery of public services were fostered. Studies that focused on reporting information were also infused with an engagement intent. For example, Contrafatto (2014) examined and theorized the process through which sustainability reporting became institutionalized in an Italian company.

As Unerman and Chapman (2014) highlighted, the theoretical depth and diversity displayed in papers in the special section, allied to the rich, nuanced empirical observations of engagement, represented both an important contribution to advancing academic insights around the roles of accounting in sustainable development (including issues of social sustainability) and demonstrated ways in which in-depth, focused and tailored theorization 
can help to advance these insights. Having demonstrated this pathway to the provision of original and rigorous insights on accounting for social sustainability, we might then expect future studies to further develop sophistication in the use of in-depth theorizations to help advance policy and practice in this area. Within the concluding section of this paper, we propose some major areas where we envisage future high quality academic studies into the roles of accounting in social sustainability could help advance policy and practice.

\section{Concluding thoughts - from retrospective to prospective}

This paper has sought to elucidate how a journal and its editor can nurture a stream of high quality and influential research in a novel area. It has done this by analysing $A O S$ 's and Hopwood's nurturing of research into certain aspects of accounting for social sustainability for several decades before this research area became widespread. Our discussion reveals how the instigation of novel research areas may initially involve the publication of risky papers driven primarily by passion. Guided by a journal editor, subsequent work then needs to combine this passion with academic rigour to yield research insights that advance society by progressively shaping policy and practice. It is this concern for rigour that we contend needs to continue to be central to research in accounting for social sustainability if purposeful knowledge is to be produced (see also: Alvesson \& Sandberg, 2013; Flyvbjerg, 2001). In the remainder of the paper we offer our perspective on what we see as some key aspects of this future research focus.

Recent work in $A O S$ has begun to address both Hopwood's (2009) and Gray's (2002) pleas for theorized engagement, albeit with greater attention being afforded to environmental as opposed to social sustainability. Despite this, numerous issues central to social sustainability, such as reporting on human rights, supply chain abuses, and fair trade, have received limited attention in $A O S$. Recent accounting for social sustainability work in $A O S$ has started to move the focus of attention away from reporting on social sustainability per se and more towards the processes through which reporting evolves and is used by stakeholder groups, as well as other aspects of accounting for social sustainability. We concur with both Hopwood's (2009) and Gray's (2002) contention that further high quality field work is vital to advancing the study of accounting for social sustainability, especially work focused on understanding the 'real world problems' that Alvesson and Sandberg $(2011,2013)$ claim management research has largely neglected. 
However, we share concerns that much research into accounting for social sustainability continues to consider motives for reporting among listed companies. While the theorization underpinning these motives has evolved and become more nuanced, we question whether additional theoretical explanations of these motives are actually adding significantly to our understanding, or if this research stream has largely exhausted the possibility of unveiling further compelling insights, with little potential for rigorously informed and welljustified research questions. We would argue that there is more potential around questions about how this reporting is constructed and used in a wide variety of organizational contexts and about non-reporting aspects of accounting for social sustainability. This latter area of questioning includes the roles accounting can play in embedding considerations underlying social sustainability into organizational decision-making at strategic, tactical and operational levels (see, Bebbington \& Thomson, 2013).

Many of the more innovative and productive examples of accounting for social sustainability may also well be emerging elsewhere than in listed company contexts such as the public sector, co-operatives, social enterprises, NGOs, and employee-owned companies like John Lewis in the UK. The recent innovation in the US and Europe of B Corporations (or Benefit Corporations) that are mandated to pursue both shareholder wealth maximisation and altruistic social goals under a statutory framework (see: Hiller, 2013) represents an intriguing context within which to extend research questions to hybrid organizational forms ${ }^{3}$. B Corporation statutes have opened up a space for social enterprises to legally articulate a dual mission, thereby implying that the nature and process of their reporting and its impacts on wider stakeholders should be of considerable research interest, particularly from an accountability and decision-making perspective.

Studying reporting and decision-making experiments among B Corporations has the potential to open up unique new examples of 'accounting for social sustainability in action', particularly where organizational logics are likely to collide, as well as guiding future reporting developments in accounting for social sustainability in conventional corporations. Addressing research questions about these new organizational contexts will help us understand better how diverse organizations seek to account for issues of social sustainability and how their frequently broader user base engages with this accounting. This would also facilitate greater use of comparative studies examining how and why various forms of

\footnotetext{
${ }^{3}$ See: http://www.bcorporation.net/. Last accessed November $2^{\text {nd }} 2015$.
} 
accounting for social sustainability proliferate and how these practices are influenced by prevailing institutional environments, thereby enhancing inter-organizational theorizing. Themes of engagement should also drive studies of how stakeholder groups such as social movements, trade unions and think tanks are using social sustainability information to construct their own accounts, and with what effects (see: O'Sullivan \& O'Dwyer, 2015). This focus on those who are perceived to need information is what initially inspired Medawar (1976), while the potential use of corporate reporting by non-shareholder groups stimulated Cooper and Essex (1977) and Harte and Owen (1987) to advance frameworks and models to guide employee groups. Future research could address questions such as what strategies and framings these groups are now mobilising to ensure improved disclosure, and to what ends (if any) this disclosure has been used.

The scope of analysis among research projects in accounting for social sustainability also needs to be expanded beyond individual organizations. Medawar (1976) questioned the credentials and commitment of accountants to designing reporting mechanisms in the public interest while Cooper and Essex (1977) endorsed them. In the four decades since Medawar's paper was published there has been extensive evidence that the public interest has been undermined by concerns to promote commercialism within professional services firms and the accounting profession (see: Malsch \& Gendron, 2013; Muzio, Brock, \& Suddaby, 2013). We need more in-depth studies of how the profession and its constituent professional bodies have mobilised around accounting for social sustainability and how this has been attached to claims to represent the public interest. The accounting profession has been active in promoting variants of sustainability reporting and, more recently, 'connected' and 'integrated' reporting. However, we have limited robust evidence about how these bodies have constructed and mobilised their engagement in the development of these new reporting forms.

Research projects also need to encompass an examination of how conflicting framings may underpin different professional accounting bodies' efforts to promote reporting on social sustainability. Of interest here would be comparisons of the way in which professional accounting bodies frame their engagement with core aspects of social sustainability such as human rights, supply chain management and employee health and safety. Moreover, as many academics have been engaging with these professional bodies on these reporting evolutions over a long period, the construction of accounts of these engagements would help further develop Hopwood's earlier accounts of his own extensive engagement efforts as well as 
allowing for reflection on the extent to which the public policy impacts Hopwood aspired to are being realised.

A recent $A O S$ paper by Murphy, O’Connell, and Ó hÓgartaigh (2013) pondered why academics studying accounting for social sustainability have neglected to undertake any active engagement in the development of the Conceptual Framework for financial reporting. The initial papers we review in this essay supported a broader conception of corporate reporting user groups than advocated within the IASB/FASB joint conceptual framework project. Murphy et al. (2013) argue that a narrowing of the definition of user groups and a simultaneous downgrading of the stewardship concept has had profound implications for the study of accounting for social sustainability in a financial reporting context (see also: Williams \& Ravenscroft, 2014). They contend that while it has ousted social accounting from its earlier position close to the centre of the reporting process to one where it now appears in stark contrast to 'mainstream' accounting, few academic efforts have emerged to problematize this trend from an accounting for social sustainability perspective. They are perplexed by this lack of meaningful researcher engagement with the Conceptual Framework project and contend that researchers interested in accounting for social sustainability do not seem to fully realise the potentially fundamental contribution that they could make to such debates. This is the form of engagement that Hopwood encouraged, aspired to, and participated in, albeit in the broader context of seeking greater examinations of accounting and the social, and accounting in action.

In our call for enhanced theorized engagement we query Gray's (2002) concern to establish a greater meta-theory for social accounting. All theory is an abstraction or simplification of reality, that we can use as a tool to better understand and analyse complex problems (Chapman 2015). Given the considerable breadth and depth of complexity underlying accounting for sustainability (Bebbington \& Larrinaga, 2014), we are concerned that a meta-theory that attempted to simplify across this vast array of complex issues would have very little practical utility in helping to advance rigorous research insights. Rather, we contend that in light of this complexity we need a range of specific refined theories, each providing a simplification of a specific aspect of this complexity, to help us transform accounting for social sustainability data into robust evidence to influence policy and practice. This focused theorisation could develop what Lukka and Vinnari (2014) refer to as 'domain theories' in the field of accounting for social sustainability aimed at developing specific sets of knowledge on the substantive areas underpinning accounting for social sustainability. 
These domain theories could then interact with broader more abstract theoretical lenses ('method theories') drawn from other fields such as organization studies or sociology that are specifically aligned with the issue(s) being studied (see: Lukka \& Vinnari, 2014, p. 1330). A meta-theory is, we believe, too blunt an analytical tool if we want to draw reliable evidence from messy, complex and unpredictable data - and could potentially act to counter any possible attempts to encourage a sense of reflexivity, invention and openness to surprises in these research endeavours.

This reflexivity and invention is partly illustrated by the range of unique empirical and theoretical insights from papers in the recent $A O S$ special section which illuminate how case study approaches can unveil surprises within empirical domains (see: Locke, 2011). It seems to us almost impossible to conceive of a broad common meta-theory that would have enabled the deep insights to be developed from this disparate range of empirical situations. It is important, however, to highlight that while we advocate theoretical variety, we are not advocating theoretical 'gap spotting' research setting up some implicit competition between theories in terms of how they develop understandings (see: Alvesson \& Sandberg, 2011). Moreover, we advocate greater problematization of the assumptions underlying existing theories, which has rather belatedly arrived in the emerging (often implicit) dismissal of crude conceptions of legitimacy theory (and it variants) in recent work on accounting for social sustainability in AOS. Overall, we recommend a cumulative theorization of 'accounting in action' in the realm of accounting for social sustainability in a wider variety of organizational contexts drawing on and, where possible, integrating a range of theories. It is through this greater theoretical sophistication enrolled in analysing and interpreting data on the roles of accounting in social sustainability that we contend that $A O S$ can best continue nurturing the development of research projects in this area of policy and practice. This effective use of nuanced theory to help capture and analyse a range of evidence on accounting for social sustainability can help to provide further rigorous answers to rigorous, well-justified, research questions in this area. 


\section{References}

Archel, P., Husillos, J., \& Spence, C. (2011). The institutionalization of unaccountability: Loading the dice of Corporate Social Responsibility discourse. Accounting, Organizations and Society. 36(6), 327-343.

Alvesson, M., \& Karreman, D. (2011). Qualitative research and theory development: Mystery as method. London: Sage.

Alvesson, M., \& Sandberg, J. (2011). Generating research questions through problematization. Academy of Management Review, 36(2), 247-271.

Alvesson, M., \& Sandberg, J. (2013). Constructing research questions: Doing interesting research. London: Sage.

Bebbington, J., Brown, J., Frame, B., \& Thomson, I. (2007). Theorizing engagement: the potential of a critical dialogic approach. Accounting, Auditing \& Accountability Journal, 20 (3), 356-381.

Bebbington J. \& Gray R. (2001). An account of sustainability: failure, success and a reconceptualization. Critical Perspectives on Accounting. 12: 557-587.

Bebbington, J., \& Dillard, J. (2009). Social sustainability: An organizational level analysis. In J. Dillard, V. Dujon, \& M. King (2009). Understanding the social dimension of sustainability. London and New York: Routledge, Taylor and Francis Group, 157-173.

Bebbington, J., \& Larrinaga, C. (2014). Accounting and sustainable development: An exploration. Accounting, Organizations and Society, 39(6), 395-413.

Bebbington, J., \& Thomson, I. (2013). Sustainable Development, Management and Accounting: Boundary Crossing. Management Accounting Research, 24(4), 277-283.

Burchell, S., Clubb, C., Hopwood, A., \& Nahapiet, J. (1980). The role of accounting in organizations and society. Accounting, Organization and Society, 5(1), 5-27.

Burchell, S., Clubb, C., \& Hopwood, A. (1985). Accounting in its social context: towards a history of value added in the United Kingdom. Accounting, Organizations and Society, $10(4), 381-413$.

Chapman, C., Cooper, D., \& Miller, P. (2009). Accounting, Organizations \& Institutions. Oxford University Press: Oxford.

Chapman, C. (2015). Researching accounting in health care: considering the nature of academic contribution, Accounting and Finance, 55(2); 397-413.

Contrafatto, M. (2014). The institutionalization of social and environmental reporting: An Italian narrative. Accounting, Organizations and Society, 39(6), 414-432.

Cooper, D., \& Essex, S. (1977). Accounting information and employee decision making. Accounting, Organizations and Society, 2(3), 201-217. 
Cooper, D., \& Sherer. M. (1984). The Value of Corporate Accounting Reports: Arguments for a Political Economy of Accounting, Accounting, Organizations and Society, 9(3-4), 207232.

Cooper, D., \& Morgan, W. (2013). Meeting the evolving corporate reporting needs of government and society: Arguments for a deliberative approach to accounting rule making. Accounting and Business Research, 43(4), 418-411.

Cooper, S., \& Owen, D. (2007). Corporate social reporting and stakeholder accountability: The missing link. Accounting, Organizations and Society, 32, 649-667.

Craft, J. (1981). Information disclosure and the role of the accountant in collective bargaining. Accounting, Organizations and Society, 6(1), 97-107.

Dillard, J., Dujon, V., \& King, M. (2009). Understanding the social dimension of sustainability. London and New York: Routledge, Taylor and Francis Group.

Everett, J., Neu, D., Rahaman, A., \& Maharaj, G. (2015). Praxis, Doxa and research methods; Reconsidering critical accounting. Critical Perspectives on Accounting. Forthcoming.

Flyvbjerg, B. (2001). Making Social Science Matter. Chicago, IL: University of Chicago Press.

Foley, B., \& Maunders, K, (1977). Accounting Information Disclosure and Collective Bargaining. London: Macmillan.

Gray, R., Owen, D., \& Maunders, K. (1987). Corporate Social Reporting: Accounting and Accountability. London: Prentice-Hall.

Gray, R. (1992). Accounting and environmentalism: an exploration of the challenge of gently accounting for accountability, transparency and sustainability. Accounting, Organizations and Society, 17(5), 399-426.

Gray, R. (2002). The social accounting project and accounting organizations and society: Privileging engagement, imaginings, new accountings and pragmatism over critique. Accounting, Organizations and Society, 27(7), 687-708.

Gray, R. (2010). Is accounting for sustainability actually accounting for sustainability and how would we know? An exploration of narratives of organizations and the planet. Accounting, Organizations and Society, 35(1), 47-62.

Gray. R., \& Milne, M. (2015). It's not what you do, it's the way that you do it? Of method and madness. Critical Perspectives on Accounting, Forthcoming.

Gray, R, Dey, C, Owen, D., Evans, R., \& Zadek, S. (1997). Struggling with the praxis of social accounting: stakeholders, accountability, audits and procedures. Accounting Auditing \& Accountability Journal, 10(3): 325-364. 
Harte, G., \& Owen, D. (1987). Fighting de-industrialisation: the role of local government social audits. Accounting, Organizations and Society, 12(2), 123-142.

Hiller, J. (2013). The Benefit Corporation and Corporate Social Responsibility. Journal of Business Ethics, 118(2), 287-301.

Hopwood, A. (1976). Editorial: The path ahead. Accounting, Organizations and Society, 1(1), $1-4$.

Hopwood, A. (1978a), Social accounting - the way ahead? Social Accounting, London: The Chartered Institute of Public Finance and Accounting (CIPFA), 53-64.

Hopwood, A. (1978b). Towards an organizational perspective or the study of accounting and information systems. Accounting, Organizations and Society, 3(1), 3-13.

Hopwood, A. (1983). On trying to study accounting in the contexts in which it operates. Accounting, Organizations and Society, 8(2-3), 287-305.

Hopwood, A. (1985) The Tale of a Committee that Never Reported: Disagreements on Intertwining Accounting with the Social. Accounting, Organizations and Society. 10(3), 361377.

Hopwood, A. (1987). The archaeology of accounting systems. Accounting, Organizations and Society, 12(3), 207-234.

Hopwood, A. (2005). Editorial: After 30 years. Accounting, Organizations and Society, 30(78), 585-586.

Hopwood, A. (2007). Whither accounting research? The Accounting Review, 82(5), 13651374.Hopwood, A. (2009). Accounting and the environment. Accounting, Organizations and Society, 34(3-4), 433-439.

Hopwood, A., Unerman, J., \& Fries, J. (Eds.). (2010). Accounting for sustainability: Practical insights. London: Earthscan.

Humphrey, C., \& Gendron, Y. (2015). What is going on? The sustainability of accounting academia. Critical Perspectives on Accounting, 26, 47-66.

Lehman, G. (1999). Disclosing new worlds: A role for social and environmental accounting and auditing. Accounting, Organizations and Society, 24(3), 217-241.

Locke, K. (2011). Field research practice in management and organizations: reclaiming its tradition of discovery. The Academy of Management Annals. 5(1), 613-652.

Lukka, K., \& Vinnari, E. (2014). Domain theory and method theory in management accounting research. Accounting, Auditing \& Accountability Journal, 27(8), 1308-1338.

Magis, K., \& Shinn, C. (2009). Emergent principles of social sustainability. In J. Dillard, V. Dujon, \& M. King (2009). Understanding the social dimension of sustainability. London and New York: Routledge, Taylor and Francis Group, 15-44. 
Malsch, B. (2013). Politicizing the experience of the accounting industry in the realm of corporate social responsibility. Accounting, Organizations \& Society, 38(2), 149-168.

Malsch, B., \& Gendron, Y. (2013). Re-theorizing change: Institutional experimentation and the struggle for domination in the field of public accounting. Journal of Management Studies, 50(5), 870-899.

McBarnet, D., Weston, S., \& Whelan, C. (1993). Adversary accounting: Strategic uses of financial information by capital and labour. Accounting, Organizations and Society, 18(1), $81-100$.

Medawar, C. (1976). The social audit: a political view. Accounting, Organizations and Society, 1(4), 389-394.

Miller, P., \& O'Leary, T. (1987). Accounting and the construction of the governable person. Accounting, Organizations and Society, 12(3), 235-265.

Murphy, T., O’Connell, V., \& Ó hÓgartaigh, C. (2013). Discourses surrounding the evolution of the IASB/FASB Conceptual Framework: What they reveal about the -living law of accounting. Accounting, Organizations and Society, 38(1), 72-81.

Muzio, D., Brock, D., \& Suddaby, R. (2013), Professions and institutional change: Towards an institutionalist sociology of the professions, Journal of Management Studies, 50(5), 699721.

Neu, D., Warsame, H., \& Pedwell, K. (1998). Managing pubic impressions: environmental disclosure in annual reports. Accounting, Organizations and Society, 23(3), 265-282.

Neu, D., Cooper, D., \& Everett, J. (2001). Critical accounting interventions. Critical Perspectives on Accounting, 12(6), 736-762.

Nicholls, A. (2010). Institutionalizing social entrepreneurship in regulatory space: Reporting and disclosure by community interest companies, Accounting, Organizations and Society, $35(4), 394-415$.

Nicholls, A. (2009). 'We do good things, don't we?': 'Blended Value Accounting' in social entrepreneurship. Accounting, Organizations and Society, 34(6-7), 755-769.

O'Dwyer, B. (2005). The construction of a social account: A case study in an overseas aid agency. Accounting, Organizations and Society, 30, 279-296.

Ogden, S., \& Bougen, P. (1985). A radical perspective on disclosure of information to trade unions. Accounting, Organizations and Society, 10(2), 211-224.

Owen, D. (1990). Towards a theory of social investment: a review essay. Accounting, Organizations and Society, 15(3), 249-266.

Owen, D., \& Lloyd, A. (1985). The use of financial information by trade union negotiators in plant level collective bargaining. Accounting, Organizations and Society, 10(3), 329-350. 
Roberts J. (2003). The manufacture of Corporate Social Responsibility: constructing corporate sensibility. Organization, 10(2), 249-265.

Rubenstein, D. (1992). Bridging the gap between green accounting and black ink. Accounting, Organizations and Society, 17(5), 501-508.

Spence, L., \& Rinaldi, L. (2014). Governmentality in accounting and accountability: A case study of embedding sustainability in a supply chain. Accounting, Organizations and Society, $39(6), 433-452$.

Thomson, I., Grubnic, S., \& Georgakopoulos, G. (2014). Exploring accounting-sustainability hybridisation in the UK public sector. Accounting, Organizations and Society, 39(6), 453476.

Tinker, A.M. (1980). Towards a political economy of accounting: an empirical illustration of the Cambridge controversies. Accounting, Organizations and Society, 5(1), 147-160.

Tinker, T., Lehman C., \& Neimark, M. (1991). Falling down the hole in the middle of the road: political quietism in corporate social reporting. Accounting Auditing \& Accountability Journal 4(2): 28-54.

Tricker, R. (1975). Research in Accountancy - A Strategy for Further Work. London: Social Science Research Council.

Unerman, J., \& Bennett, M. (2004). Increased stakeholder dialogue and the internet: Towards greater corporate accountability or reinforcing capitalist hegemony? Accounting, Organizations and Society, 29, 685-707.

Unerman, J., \& Zappettini, F. (2014). Incorporating materiality considerations into analyses of absence from sustainability reporting. Social and Environmental Accountability Journal 34(3): 172-186.

Williams, P., \& Ravenscroft, S. (2014). Rethinking decision-usefulness, Forthcoming, Contemporary Accounting Research. $<$ http://onlinelibrary.wiley.com/doi/10.1111/1911$3846.12083 / \mathrm{pdf}>$. 